\title{
ANALISIS STRATEGI MENYEDERHANAKAN MASALAH SERUPA DAN SUDUT PANDANG LAIN PADA PERMASALAHAN NON RUTIN PENJUMLAHAN FUNGSI
}

\author{
Kartika Maharani ${ }^{1)}$, Rubono Setiawan ${ }^{2)}$ \\ ${ }^{1), 2)}$ FKIP Matematika Univeritas Sebelas Maret Surakarta \\ Email: maharanikartika396@gmail.com ${ }^{1)}$, rubono.matematika@gmail.com ${ }^{2)}$
}

\begin{abstract}
The problem of Addition Operation of Functions often emerges in Junior National Science and Math Olympiads at the regional level, provincial level, and national level. Non-routine questions related to the addition of functions tested In the Junior National Science Math Olympiad are more concern on the problem-solving. The questions have complex types and these types cannot directly solved by common routine procedures. Systematic-logical thinking and high level of understanding ability are required to solve the problem. There are some basic strategies which can be implemented to find the right solutions. Blended strategy plays a significant role to solve the problem. This research will discuss about the strategy to simplify equal group problem from another point of view in order to solve the addition of functions problem in the Junior National Science Math Olympiad. The implementation of the strategy is based on the Polya's ProblemSolving Techniques.
\end{abstract}

Keywords: equivalent problem, other point of view, problem-solving, polya's problemsolving techniques, problem-solving strategy

\section{PENDAHULUAN}

Pada perkuliahan Aljabar telah dipelajari tentang konsep fungsi. Permasalahan tentang fungsi tersebut sering juga muncul dalam Olimpiade Sains Nasional Matematika SMP baik tingkat kabupaten/kota, provinsi, maupun di tingkat Nasional. Pada Olimpiade Sains Nasional Matematika SMP, soal-soal yang diujikan terkait dengan fungsi berorientasi pada soal pemecahan masalah. Suatu pertanyaan akan menjadi masalah hanya jika pertanyaan itu menunjukkan adanya suatu tantangan yang tidak dapat dipecahkan oleh prosedur rutin yang sudah diketahui pelaku (Fajar, 2009).

Soal-soal tersebut memiliki karakteristik soal non rutin, dimana soal tersebut merupakan soal yang strategi penyelesaiannya tidak langsung terlihat. Dalam menghadapi soal Olimpiade
Sains Nasional Matematika SMP terkait dengan materi aljabar bertipe fungsi ini, berpikir pemecahan masalah perlu dimiliki oleh setiap siswa. Menurut Lencher (dalam Anonim, 2014: 3), pemecahan masalah matematika adalah proses menerapkan pengetahuan matematika yang telah diperoleh sebelumnya ke dalam situasi baru yang belum dikenal. Pembicaraan mengenai pemcahan masalah matematika tidak dapat terlepas dari tokoh utamanya, yaitu George Polya. Menurut Polya (dalam Sudarman, 2016: 163) bahwa pemecahan masalah dalam matematika terdiri atas empat langkah pokok, yaitu: memahami masalah, membuat rencana untuk menyelesaikan masalah, melaksanakan penyelesaian soal, memeriksa ulang jawaban yang diperoleh. 
Seorang pemecah masalah terampil tidak dapat terlepas dari kemampuan berpikir sistematis, logis, dan kritis serta kegigihan dalam memecahkan masalah yang dihapainya (Anonim, 2014: 1). Huang (dalam Sudarman, 2016: 163) menyatakan bahwa keterampilan pemecahan masalah yang baik adalah kunci untuk memperoleh solusi sukses dalam matematika. Siswa harus memahami secara mendalam karakteristik dan konsep materi fungsi yang akan diujikan dalam Olimpiade Sains Nasional Matematika SMP, karena materi terkait fungsi yang diujikan ini berbeda situasinya dengan materi fungsi yang diajarkan di dalam kelas saat pembelajaran biasa karena soal yang diujikan merupakan permasalahan non rutin. Selain itu siswa juga harus memahami secara mendalam strategi-strategi apa yang diperlukan dalam menyelesaikan permasalahan terkait materi tersebut agar tidak membuang waktu. Salah satu permasalahan terkait dengan materi fungsi yang diujikan dalam Olimpiade Sains Nasional Matematika SMP yaitu penjumlahan fungsi. Namun materi penjumlahan ini jauh lebih kompleks dari materi operasi penjumlahan fungsi biasa dimana kita dituntut untuk mengoperasikan nilai suatu fungsi dengan cacahan nilai fungsi yang banyak atau dengan cacah yang lebih kompleks. Dan soal tersebut mempunyai bentuk-bentuk yang rumit. Soal ini biasanya menuntut kita untuk mencari nilai suatu fungsi $f(x)$ dengan $x$ tertentu apabila telah diketahui terlebih dahulu rumus suatu fungsi $f(x)$, kemudian kita dituntut untuk mencari hasil dari penjumlahan nilai suatu fungsi $f(x)$ tersebut untuk $x$ tertentu. Ada beberapa strategi yang sering digunakan menurut Polya (dalam Dhurori dan Markaban, 2010: 9-10) diantaranya adalah strategi mencoba- coba, membuat diagram, mencobakan pada soal yang lebih sederhana, membuat tabel, menemukan pola, memecah tujuan, memperhitungkan setiap kemungkinan, berpikir logis, bergerak dari belakang, dan mengabaikan hal yang tidak mungkin. Dalam banyak permasalahan dibutuhkan lebih dari satu jenis strategi penyelesaian untuk dapat menyelesaikan permasalahan tersebut.

Berdasarkan uraian di atas, penulis tertarik untuk membahas mengenai kombinasi strategi penyelesaian dalam menyelesaikan masalah penjumlahan fungsi pada Olimpiade Sains Nasional Matematika SMP, dalam tulisan ini akan dibahas mengenai kombinasi strategi menyederhanakan masalah serupa dan melihat dari sudut pandang lain. Selain itu, penulis juga akan membahas mengenai penerapan strategi tersebut berdasarkan pada langkahlangkah Polya untuk penyelesaian masalah penjumlahan fungsi pada Olimpiade Sains Nasional Matematika SMP. Tujuan dari penulisan ini adalah untuk mengetahui bagaimana penggunaan kombinasi strategi menyederhanakan masalah serupa dan melihat dari sudut pandang lain untuk menyelesaikan permasalahan terkait penjumlahan fungsi dalam Olimpiade Sains Nasional Matematika SMP dan penerapannya berdasarkan langkah Polya.

\section{PEMBAHASAN}

Soal-soal matematika bertipe penjumlahan fungsi dalam Olimpiade Sains Nasional Matematika SMP merupakan soal non rutin yang mendorong siswa berpikir logis, menambah pamahaman konsep siswa, dan melatih siswa berpikir pemecahan masalah. Untuk soal terkait penjumlahan fungsi yang diujikan, biasanya untuk mencari hasil dari 
penjumlahan nilai suatu fungsi, yang rumus fungsi $f(x)$ nya sudah diketahui sehingga kita tinggal mensubstitusikan nilai fungsi $f(x)$ tersebut untuk nilai $x$ yang dikehendaki pada soal. Namun ada pula soal yang menghendaki kita untuk mencari hasil dari penjumlahan nilai suatu fungsi, yang rumus fungsi $f(x)$ nya belum diketahui, tetapi hanya diketahui nilai fungsi $f(x)$ tersebut untuk $x$ tertentu. Kita harus terlebih dahulu menemukan rumus fungsi $f(x)$ secara umum agar rumus fungsi $f(x)$ tersebut dapat diterapkan untuk mencari nilai fungsi $f(x)$ untuk nilai $x$ yang lain , sehingga kita dapat mencari hasil penjumlahan fungsi-fungsi tersebut untuk $x$ yang dikehendaki pada soal.

Dalam kurun waktu sepuluh tahun ini, soal Olimpiade Sains Nasional Matematika SMP terkait dengan penjumlahan fungsi, tidak selalu muncul dalam setiap tingkatan seleksi, ada yang dimunculkan hanya pada seleksi tingkat kabupaten/kota saja, adapula yang dimunculkan hanya pada tingkat provinsi maupun tingkat nasional saja. Adapun soal yang terkait penjumlahan fungsi ini dalam setiap bagian soal, baik bagian pilihan ganda maupun isian singkat tidak banyak dan tidak selalu dimunculkan, hanya satu soal yang dimunculkan pada bagian pilihan ganda. Namun, ada juga soal yang dimunculkan dalam bagian isian singkat. Menurut analisa penulis, soal terkait penjumlahan fungsi ini lebih sering muncul pada saat seleksi tingkat provinsi bagian isian singkat. Tetapi tidak jarang pada seleksi-seleksi tingkat yang lainnya soal terkait penjumlahan fungsi ini tidak dimunculkan, soal yang dimunculkan mengenai materi fungsi tetapi hanya sebatas pada mencari nilai fungsi $f(x)$ saja.

Pada soal penjumlahan fungsi yang sering diujikan pada Olimpiade Sains Nasional Matematika SMP, memiliki karakteristik untuk menghitung jumlah nilai fungsi $f(x)$ untuk nilai $x$ yang dikehendaki dalam soal. Nilai $x$ yang dikehendaki dalam soal cenderung mengarah kepada nilai $\mathrm{x}$ dengan rentang antara nilai $\mathrm{x}$ pertama dengan nilai $\mathrm{x}$ terakhir adalah rentang yang besar. Sebagai contoh, ada soal yang menuntut kita menghitung jumlah nilai fungsi $f(x)$ untuk nilai $x$, dari $x=1$ hingga $x=2007$. Rentang nilai $x$ yang ditanyakan sangat besar yaitu dari $x=1$ hingga $x=2007$. Apabila kita hendak mencari nilai fungsi $f(x)$ tersebut untuk masingmasing nilai $x$, tentunya akan sangat memakan waktu karena nilai $x$ nya sangat banyak dan belum lagi apabila kita melakukan kesalahan dalam perhitungan menjumlahkan nilai fungsi masing-masing $x$ tersebut. Untuk itu, kita harus mengetahui strategi-strategi yang dapat digunakan dalam menyelesaikan permasalahan menghitung penjumlahan fungsi $f(x)$ untuk $\mathrm{x}$ dengan rentang yang besar, tanpa kita harus menghitung nilai fungsi $f(x)$ tersebut untuk masing-masing nilai $x$. Untuk dapat menyelesaikan soal bertipe penjumlahan fungsi, kita dapat mengkombinasikan antara strategi menyederhanakan masalah serupa dengan strategi melihat dari sudut pandang lain. Penggunaan kombinasi strategi ini dapat mempersingkat perhitungan.

\section{Menyederhanakan Masalah Serupa}

Strategi menyederhanakan masalah serupa merupakan strategi yang dapat digunakan pada soal non rutin bertipe penjumlahan fungsi ketika kita berhadapan dengan permasalahan untuk menjumlahkan nilai-nilai fungsi dengan penjumlahan yang sangat banyak dan rentang nilai $\mathrm{x}$ yang besar. Strategi ini digunakan supaya dapat mempersingkat perhitungan dalam jumlah yang besar dan dilakukan dengan mencobakan 
permasalahan kompleks ke suatu bentuk serupa yang lebih sederhana, sehingga kita akan dapat menemukan suatu pola penyelesaian. Kemudian, pola tersebut dapat diterapkan untuk permasalahan kompleks sebelumnya. Langkah yang dapat dilakukan pada strategi ini dalam menyelesaikan permasalahan non rutin bertipe penjumlahan fungsi adalah mencobakan bentuk penjumlahan fungsi yang ditanyakan ke dalam bentuk penjumlahan fungsi yang serupa namun lebih sederhana.

Pada langkah ini kita membentuk penjumlahan fungsi yang serupa dengan soal namun banyaknya penjumlahan lebih sedikit daripada banyaknya penjumlahan yang ditanyakan atau kita dapat mempersingkat rumus dengan menyederhanakan masalah serupa. Langkah berikutnya yaitu menyelesaikan bentuk penjumlahan fungsi yang lebih sederhana tersebut dengan memanfaatkan bentuk aljabar atau manipulasi aljabar untuk mendapatkan pola penyelesaian terhadap permasalahan yang lebih sederhana tersebut. Setelah didapat pola penyelesaian untuk permasalahan penjumlahan fungsi yang lebih sederhana, maka pola penyelesaian tersebut nantinya juga akan berlaku atau dapat diterapkan untuk permasalahan penjumlahan fungsi yang lebih banyak seperti dalam soal yang ditanyakan.

Misalnya untuk menentukan penjumlahan fungsi $f(x)$ berikut:

1. Diketahui fungsi bilangan real $f(x)$ $=\frac{x}{1-x}, x \neq 1$. Tentukan nilai dari $f(2007)+f(2006)+f(2005)+\ldots+f(3)+$ $f(2)+f\left(\frac{1}{2}\right)+f\left(\frac{1}{3}\right)+\ldots+f\left(\frac{1}{2007}\right)$.

\section{(Olimpiade Sains Tingkat Provinsi 2007 Bagian B)}

Soal tersebut dapat diselesaikan dengan strategi ini karena melibatkan penjumlahan yang sangat banyak yaitu menjumlahkan dari nilai fungsi $f(x)$ untuk $x=\frac{1}{2007}$ sampai $f(x)$ untuk $x=2007$ dan penjumlahan nilai-nilai fungsi yang sangat besar dan cacahnya banyak. Apabila kita harus menghitung masing-masing nilai fungsi $f(x)$ untuk $x=\frac{1}{2007}$ sampai $f(x)$ untuk $x$ $=2007$ kemudian hasilnya baru dijumlahkan, akan sangat memakan waktu. Langkah yang harus dilakukan terlebih dahulu adalah mencobakan bentuk penjumlahan fungsi yang ditanyakan ke dalam bentuk penjumlahan fungsi yang serupa namun lebih sederhana, dengan memanfaatkan satu operasi penjum-lahan untuk menjumlahakan dua fungsi yang serupa dengan bentuk permasalahan yang ditanyakan, maka kita dapat mempersingkat rumus fungsinya untuk permasalahan yang lebih kompleks seperti yang ditanyakan pada soal.

Adapun masalah yang lebih sederhana namun serupa dengan pertanyaan yaitu $f\left(\frac{1}{n}\right)+f(n), \quad$ dan menerapkan rumus fungsi yang diketahui dalam soal ke permasalahan sederhana. Kemudian selesaikan penjumlahan fungsi yang lebih sederhana tersebut dengan manipulasi aljabar. Setelah menyelesaikan permasalahan tersebut maka akan diperoleh pola penyelesaian $f\left(\frac{1}{n}\right)+f(n)=1 \quad$ yang kemudian dapat digunakan untuk menghitung penjumlahan fungsi yang ditanyakan, dengan perhitungan yang lebih cepat dan sederhana.

2. Diketahu $\mathrm{n}$ adalah bilangan bulat positif. Jika $f(n)=\frac{4 n+\sqrt{4 n^{2}-1}}{\sqrt{2 n+1}+\sqrt{2 n-1}}$. Tentukan $f(13)+f(14)+f(15)+\ldots+$ $f(112)$. 


\section{(Olimpiade Sains Tingkat Nasional 2012 Bagian B)}

Soal tersebut dapat diselesaikan dengan strategi ini karena melibatkan penjumlahan yang sangat banyak yaitu menjumlahkan dari nilai fungsi $f(x)$ untuk $x=13$ sampai $f(x)$ untuk $x=112$ dan penjumlahan nilai-nilai fungsi yang sangat besar dan cacahnya banyak. Apabila kita harus menghitung masing-masing nilai fungsi $f(x)$ untuk $x=13$ sampai $f(x)$ untuk $x=$ 112 kemudian hasilnya baru dijumlahkan, akan sangat memakan waktu. Langkah yang harus dilakukan terlebih dahulu adalah mencobakan bentuk penjumlahan fungsi yang ditanyakan ke dalam bentuk penjumlahan fungsi yang serupa namun lebih sederhana.

Dengan memanfaatkan satu operasi penjumlahan untuk menjumlahakan dua fungsi yang serupa dengan bentuk permasalahan yang ditanyakan, maka kita dapat mempersingkat rumus fungsinya untuk permasalahan yang lebih kompleks seperti yang ditanyakan pada soal. Adapun masalah yang lebih sederhana namun serupa dengan pertanyaan yaitu $f(a)+f(a+1)$. Kemudian selesaikan penjumlahan fungsi yang lebih sederhana tersebut dengan memanfaatkan rasionalisasi bentuk akar. Setelah menyelesaikan permasalahan tersebut maka akan diperoleh pola penyelesaian $f(a)+f(a+1)=\frac{\sqrt{(2 a+3)^{3}}-\sqrt{(2 a-1)^{3}}}{2} \quad \mathrm{y}$ ang kemudian dapat digunakan untuk menghitung penjumlahan fungsi yang ditanyakan, dengan perhitungan yang lebih cepat dan sederhana.
3. Untuk $x$ bilangan real, dirumuskan suatu fungsi: $f(x)=\frac{2}{2+4^{x}}$. Maka hitunglah hasil penjumlahan berikut: $f\left(\frac{1}{2014}\right)+f\left(\frac{2}{2014}\right)+\ldots+f\left(\frac{2013}{2014}\right)$. (Olimpiade Sains Tingkat Provinsi 2014 Bagian B)

Soal tersebut dapat diselesaikan dengan strategi ini karena melibatkan penjumlahan yang sangat banyak yaitu menjumlahkan dari nilai fungsi $f(x)$ untuk $x=\frac{1}{2014}$ sampai $f(x)$ untuk $x=\frac{2013}{2014}$ dan penjumlahan nilai-nilai fungsi yang sangat besar dan cacahnya banyak. Apabila kita harus menghitung masing-masing nilai fungsi $f(x)$ untuk $x=\frac{1}{2014}$ sampai $f(x)$ untuk $x=$ $\frac{2013}{2014}$ kemudian hasilnya baru dijumlahkan, akan sangat memakan waktu. Langkah yang harus dilakukan terlebih dahulu adalah mencobakan bentuk penjumlahan fungsi yang ditanyakan ke dalam bentuk penjumlahan fungsi yang serupa namun lebih sederhana.

Dengan memanfaatkan satu operasi penjumlahan untuk menjumlahakan dua fungsi yang serupa dengan bentuk permasalahan yang ditanyakan, maka kita dapat mempersingkat rumus fungsinya untuk permasalahan yang lebih kompleks seperti yang ditanyakan pada soal. Adapun masalah yang lebih sederhana namun serupa dengan pertanyaan yaitu

$f(a)+f(1-a)$, a bilangan real. Kemudian selesaikan penjumlahan fungsi yang lebih sederhana tersebut dengan manipulasi aljabar. Setelah menyelesaikan permasalahan tersebut maka akan diperoleh pola penyelesaian $f(a)+f(1-a)=1$, yang kemudian dapat digunakan untuk menghitung 
penjumlahan fungsi yang ditanyakan, dengan perhitungan yang lebih cepat dan sederhana.

4. Didefinisikan fungsi $f(\mathrm{n})=2^{\mathrm{n}-1}+2^{\mathrm{n}}$ $-2^{\mathrm{n}+1}$, untuk setiap bilangan asli $\mathrm{n}$. Nilai $\quad f(1)+f(2)+f(3)+f(4)+f(5)$ adalah ...

\section{(Olimpiade Sains Tingkat Kabupaten/Kota 2015 Bagian A)}

Soal tersebut dapat diselesaikan dengan strategi ini walaupun rentang nilai $x$ yang ditanyakan untuk masing-masing fungsi $f(x)$ tidak banyak, namun dengan penggunaan strategi ini akan jauh lebih efisien. Langkah yang harus dilakukan terlebih dahulu adalah mencobakan bentuk penjumlahan fungsi yang ditanyakan ke dalam bentuk penjumlahan fungsi yang serupa namun lebih sederhana.

Dengan memanfaatkan satu operasi penjumlahan untuk menjumlahakan dua fungsi yang serupa dengan bentuk permasalahan yang ditanyakan, maka kita dapat mempersingkat rumus fungsinya untuk permasalahan yang lebih kompleks seperti yang ditanyakan pada soal. Adapun masalah yang lebih sederhana namun serupa dengan pertanyaan yaitu

$f(a)+f(a+1)$; a bilangan asli. Kemudian selesaikan penjumlahan fungsi yang lebih sederhana tersebut dengan memanfaatkan memanfaatkan sifat perpangkatan. Setelah menyelesaikan permasalahan tersebut maka akan diperoleh pola penyelesaian $f(a)+f(a+1)=-3 \cdot 2^{a-1}$. Kemudian rumus fungsi tersebut dapat digunakan untuk menghitung penjumlahan fungsi yang ditanyakan, dengan perhitungan yang lebih cepat dan sederhana.
Jadi, pada strategi menyederhanakan masalah serupa, permasalahan dibuat sehingga terlihat lebih sederhana dan mudah untuk dipecahkan dengan mencobakan permasalahan asli ke dalam permasalahan yang lebih sederhana namun serupa dengan permasalahan asli.

\section{Melihat dari Sudut Pandang Lain}

Dalam menyelesaikan permasalahan matematika bertipe penjumlahan fungsi dengan menghitung secara langsung masing-masing nilai fungsi kemudian nilai-nilai fungsi tersebut kita jumlahkan sesuai yang ditanyakan pada soal memang memberikan solusi, tetapi belum tentu cara tersebut efisien. Apabila yang ditanyakan adalah untuk menghitung jumlah nilai fungsi $f(x)$ untuk nilai $x$ dengan rentang antara nilai $\mathrm{x}$ pertama dengan nilai $\mathrm{x}$ terakhir adalah rentang yang besar maka akan sangat memakan waktu atau tidak efisien. Terkadang, akan sangat menguntungkan apabila pemecah masalah mencoba melihat permasalahan dari sudut pandang yang berbeda atau pemecah masalah dapat merubah pandangannya terhadap permasalahan ke dalam bentuk lain. Permasalahan tersebut akan lebih mudah diselesaikan dengan pola-pola penyelesaiaan yang terbentuk.

Pada permasalahan penjumlahan fungsi ini apabila kita perhatikan secara cermat, susunan penjumlahan fungsi pada soal dapat dibuat menjadi susunan penjumlahan fungsi dalam bentuk lain yang memiliki pola penyelesaian yang lebih mudah dan efisien. Perubahan susunan penjumlahan fungsi pada soal tidak akan mengubah maksud soal. Kita hanya melakukan manipulasi bentuk soal saja dengan memanfaatkan strategi melihat dari sudut pandang lain. Dengan 
memanfaatkan strategi melihat dari sudut pandang lain, perhitungan akan lebih sederhana dan lebih efisien. Misalnya pada permasalahan :

1. Diketahui fungsi bilangan real $f(x)$ $=\frac{x}{1-x}, x \neq 1$. Tentukan nilai dari $f(2007)+f(2006)+f(2005)+\ldots+f(3)+$ $f(2)+f\left(\frac{1}{2}\right)+f\left(\frac{1}{3}\right)+\ldots+f\left(\frac{1}{2007}\right)$.

( Olimpiade Sains Tingkat Provinsi 2007 Bagian B )

Kita dapat melihat susunan penjumlahan fungsi yang ditanyakan dari sudut padang yang lain yaitu kita dapat menyusunnya menjadi bentuk $\left[f\left(\frac{1}{2}\right)+f(2)\right]+\left[f\left(\frac{1}{3}\right)+f(3)\right]+\ldots+\left[f\left(\frac{1}{2005}\right)\right.$ $+$

$f(2005)]+\left[f\left(\frac{1}{2006}\right)+f(2006)\right]+[f($ $\left.\left.\frac{1}{2007}\right)+f(2007)\right]$, perubahan bentuk susunan penjumlahan tidak merubah maksud soal.

2. Diketahu $\mathrm{n}$ adalah bilangan bulat positif. Jika $f(n)=\frac{4 n+\sqrt{4 n^{2}-1}}{\sqrt{2 n+1}+\sqrt{2 n-1}}$. Tentukan $f(13)+f(14)+f(15)+\ldots+$ $f(112)$.

\section{( Olimpiade Sains Tingkat Nasional 2012 Bagian B )}

Permasalahan fungsi pada soal terdiri dari 100 buah fungsi yaitu dari $f(13)$ hingga $f(112)$, dengan melihat permasalahan dari sudut pandang lain, kita dapat mengelompokkan dua fungsi yang berurutan, sehingga nantinya kita mendapatkan 50 pasang fungsi yang sudah dikelompokkan, kita dapat menyusunnya menjadi bentuk $[f(13)+f(14)]+[f(15)+f(16)]+\ldots+[f($ $111)+f(112)]$, perubahan bentuk susunan penjumlahan tidak merubah maksud soal.

3. Untuk $x$ bilangan real, dirumuskan suatu fungsi: $f(x)=\frac{2}{2+4^{x}}$. Maka hitunglah hasil penjumlahan berikut: $f\left(\frac{1}{2014}\right)+f\left(\frac{2}{2014}\right)+\ldots+f\left(\frac{2013}{2014}\right)$. ( Olimpiade Sains Tingkat Provinsi 2014 Bagian B )

Pada soal ini kita dapat melihat susunan penjumlahan fungsi yang ditanyakan dari sudut pandang lain yaitu kita dapat menyusunnya menjadi bentuk $\left[f\left(\frac{1}{2014}\right)+f\left(\frac{2013}{2014}\right)\right]+\left[f\left(\frac{2}{2014}\right)+f\left(\frac{2012}{2014}\right)\right]$ $+\ldots+\left[f\left(\frac{1005}{2014}\right)+f\left(\frac{1009}{2014}\right]\right)+f\left(\frac{1007}{2014}\right)$ $+\left[f\left(\frac{1006}{2014}\right)+f\left(\frac{1008}{2014}\right)\right], \quad$ perubahan bentuk susunan penjumlahan tidak merubah maksud soal.

4. Didefinisikan fungsi $f(\mathrm{n})=2^{\mathrm{n}-1}+2^{\mathrm{n}}$ $-2^{\mathrm{n}+1}$, untuk setiap bilangan asli $\mathrm{n}$. Nilai $\quad f(1)+f(2)+f(3)+f(4)+f(5)$ adalah ...

\section{(Olimpiade Sains Tingkat Kabupaten/Kota 2015 Bagian A )}

Karena ada 5 buah fungsi dan dengan melihat permasalahan dari sudut pandang lain, maka kita dapat mengelompokkan dua fungsi yang berurutan, sehingga akan didapatkan 2 pasang fungsi yang dikelompokkan dan satu fungsi yang tersisa, dapat dihitung tersendiri

$[f(1)+f(2)]+[f(3)+f(4)]+f(5)$

perubahan bentuk susunan penjumlahan tidak merubah maksud soal.

Jadi, pada strategi melihat dari sudut pandang lain, permasalahan dibuat ke dalam susunan penjumlahan bentuk lain sehingga lebih mudah dan efisien untuk dipecahkan dengan manipulasi bentuk soal dan perubahan bentuk susunan penjumlahan tidak merubah maksud soal.

\section{Penggunaan Kombinasi Strategi Menyederhanakan Masalah Serupa dan Sudut Pandang Lain dalam}




\section{Penyelesaian Masalah Matematika Non Rutin Bertipe Penjumlahan Fungsi}

Dalam

menyelesaikan

permasalahan matematika non rutin bertipe penjumlahan fungsi, kita dapat memanfaatkan kombinasi strategi menyederhanakan masalah serupa dan strategi melihat dari sudut pandang lain sekaligus. Langkah yang dapat dilakukan dalam penggunaan kombinasi strategi ini, yang pertama adalah menggunakan strategi menyederhanakan masalah serupa hingga didapat pola penyelesaian dari masalah yang lebih sederhana. Pada langkah ini, mencobakan permasalahan penjumlahan fungsi yang ditanyakan pada soal ke dalam bentuk penjumlahan fungsi yang lebih sederhana namun serupa dengan soal. Selesaikan permasalahan yang lebih sederhana tersebut sehingga didapat pola penyelesaiannya. Langkah kedua yang dapat dilakukan adalah melihat susunan penjumlahan fungsi yang ditanyakan dari sudut pandang lain. Pada langkah ini, susunan penjumlahan fungsi dapat dirubah sehingga pola penyelesaian pada strategi menyederhanakan masalah serupa dapat diterapkan pada permasalahan yang ditanyakan pada soal.

Adapun penggunaanya kombinasi strateginya dengan menerapkan langkah Polya sebagai berikut:

1. Diketahui fungsi bilangan real $f(x)$ $=\frac{x}{1-x}, x \neq 1$. Tentukan nilai dari $f(2007)+f(2006)+f(2005)+\ldots+f(3)+$ $f\left(2+f\left(\frac{1}{2}\right)+f\left(\frac{1}{3}\right)+\ldots+f\left(\frac{1}{2007}\right)\right.$.

\section{( Olimpiade Sains Tingkat} Provinsi 2007 Bagian B )

a. Memahami masalah

Diketahui:

$f(x)=\frac{x}{1-x}, x \neq 1$

Ditanya:

$$
\begin{aligned}
& f(2007)+f(2006)+f(2005)+\ldots+f \\
& (3)+f(2)+f\left(\frac{1}{2}\right)+f\left(\frac{1}{3}\right)+\ldots+f\left(\frac{1}{2007}\right) .
\end{aligned}
$$

b. Menyusun strategi

Strategi yang akan digunakan adalah kombinasi strategi menyederhanakan masalah serupa dan strategi sudut pandang lain.

c. Melakukan strategi yang dipilih

a) Strategi menyederhanakan masalah serupa :

$$
\begin{aligned}
f\left(\frac{1}{n}\right)+f(n) & =\left(\frac{\frac{1}{n}}{1-\frac{1}{n}}\right)+\left(\frac{n}{1-n}\right) \\
& =\left(\frac{1}{n-1}\right)+\left(\frac{n}{1-n}\right) \\
& =\left(\frac{n-1}{1-n}\right) \\
& =-1
\end{aligned}
$$

b) Melihat dari sudut pandang lain

$f(2007)+f(2006)+f(2005)+$. .+

$$
f(3)+f(2)+f\left(\frac{1}{2}\right)+f\left(\frac{1}{3}\right)+\ldots+f(
$$$$
\left.\frac{1}{2007}\right)=
$$$$
\left[f\left(\frac{1}{2}\right)+f(2)\right]+\left[f\left(\frac{1}{3}\right)+f(3)\right]+\ldots+
$$$$
\left[f\left(\frac{1}{2005}\right)+f(2005)\right]+\left[f\left(\frac{1}{2006}\right)+\right.
$$$$
f(2006)]+\left[f\left(\frac{1}{2007}\right)+f(2007)\right] \text {, }
$$

gunakan pola penyelesaian pada langkah a) sehingga diperoleh

$=-1+(-1)+(-1)+(-1)+. .+$ $(-1)$

karena (-1) ada sebanyak 2006 suku, maka dapat dituliskan menjadi

$=2006 .(-1)$

$=-2006$

d. Meneliti kembali pekerjaan yang telah dilakukan

Kita dapat meneliti kembali pekerjaan yang telah dilakukan dengan mengecek setiap langkah yang dilakukan apakah ada perhitungan yang terlewatkan atau tidak, 
ketelitian, dan apakah antara merencanakan strategi dan melaksanakan strategi telah sesuai.

2. Diketahu $\mathrm{n}$ adalah bilangan bulat positif. Jika $f(n)=\frac{4 n+\sqrt{-1+4 n^{2}}}{\sqrt{2 n+1}+\sqrt{2 n-1}}$. Tentukan $f(13)+f(14)+f(15)+\ldots+$ $f(112)$.

( Olimpiade Sains Tingkat Provinsi 2012 Bagian B )

a. Memahami masalah

Diketahui:

$f(n)$ $=$ $\frac{4 n+\sqrt{-1+4 n^{2}}}{\sqrt{2 n+1}+\sqrt{2 n-1}} ; n$ bilangan bulat positif

Ditanya:

Nilai $\quad f(13)+f(14)+f(15)+\ldots+$ $f(112)$.

b. Menyusun strategi

Strategi yang akan digunakan adalah kombinasi strategi menyederhanakan masalah serupa dan strategi sudut pandang lain.

c. Melakukan strategi yang dipilih

a) Strategi menyederhanakan masalah serupa

$$
\begin{aligned}
& f(a)=\frac{4 a+\sqrt{4 a^{2}-1}}{\sqrt{2 a+1}+\sqrt{2 a-1}} \\
& \frac{\sqrt{2 a+1}-\sqrt{2 a-1}}{\sqrt{2 a+1}-\sqrt{2 a-1}} \\
& =\quad\left[\left(4 a(\sqrt{2 a+1}-\sqrt{2 a-1})+\sqrt{4 a^{2}-1}(\sqrt{2 a+1}-\right.\right. \\
& \frac{\sqrt{2 a-1)}]}{2} \\
& =\quad \frac{\left.\sqrt{(2 a+1)(2 a-1)^{2}}\right]}{2} \\
& {\left[\left(4 a(\sqrt{2 a+1}-\sqrt{2 a-1})+\sqrt{(2 a-1)(2 a+1)^{2}}-\right.\right.} \\
& =\quad[(4 a(\sqrt{2 a+1}-\sqrt{2 a-1})+(2 a+1) \sqrt{(2 a-1)}- \\
& \frac{(2 a-1) \sqrt{(2 a+1)}]}{2} \\
& =\quad
\end{aligned}
$$

$$
\begin{aligned}
& \frac{[(4 a-(2 a-1)) \sqrt{2 a+1}+(-4 a+(2 a+1))}{\sqrt{(2 a-1)]}} \\
& 2 \\
& = \\
& \frac{(2 a+1) \sqrt{2 a+1}-(2 a-1) \sqrt{2 a-1}}{2} \\
& =\frac{\sqrt{(2 a+1)^{3}}-\sqrt{(2 a-1)^{3}}}{2}
\end{aligned}
$$

Sehingga diperoleh

$$
\begin{aligned}
& f(a)=\frac{\sqrt{(2 a+1)^{3}}-\sqrt{(2 a-1)^{3}}}{2} \\
& f(a)+f(a+1)=\frac{\sqrt{(2 a+3)^{3}}-\sqrt{(2 a-1)^{3}}}{2}
\end{aligned}
$$

b) Melihat dari sudut pandang lain

$$
\begin{aligned}
& f(13)+f(14)+f(15)+\ldots+f(112) \\
& =[f(13)+f(14)]+\quad[f(15)+f(16)] \\
& +\ldots+[f(111)+f(112)] \\
& \text { Gunakan pola penyelesaian pada } \\
& \text { langkah a), sehingga diperoleh } \\
& = \\
& {\left[\sqrt{29^{3}}-\sqrt{25^{3}}+\sqrt{33^{3}}-\sqrt{29^{3}}+\cdots+\sqrt{221^{3}}-\sqrt{217^{3}}\right.} \\
& +\sqrt{225^{3}}-\sqrt{221^{3}} \\
& =\frac{-\sqrt{25^{3}}+\sqrt{225^{3}}}{2} \\
& =\frac{-\left(5^{2}\right)^{\frac{3}{2}}+\left(15^{2}\right)^{\frac{3}{2}}}{2} \\
& =\frac{-125+3375}{2} \\
& =1625
\end{aligned}
$$

d. Meneliti kembali pekerjaan yang telah dilakukan

Kita dapat meneliti kembali pekerjaan yang telah dilakukan dengan mengecek setiap langkah yang dilakukan apakah ada perhitungan yang terlewatkan atau tidak, ketelitian, dan apakah antara merencanakan strategi dan melaksanakan strategi telah sesuai.

3. Untuk $x$ bilangan real, dirumuskan suatu fungsi: $f(x)=\frac{2}{2+4^{x}}$. Maka hitunglah hasil penjumlahan berikut: $f\left(\frac{1}{2014}\right)+f\left(\frac{2}{2014}\right)+\ldots+f\left(\frac{2013}{2014}\right)$. 


\section{( Olimpiade Sains Tingkat Provinsi 2014 Bagian B )}

a. Memahami masalah

Diketahui:

$f(x)=\frac{2}{2+4^{x}}, x$ bilangan real

Ditanya:

Nilai

$f\left(\frac{1}{2014}\right)+f\left(\frac{2}{2014}\right)+\ldots+f\left(\frac{2013}{2014}\right)$

b. Menyusun strategi

Strategi yang akan digunakan adalah kombinasi strategi menyederhanakan masalah serupa dan strategi sudut pandang lain.

c. Melakukan strategi yang dipilih

a) Strategi menyederhanakan masalah serupa

$$
\begin{gathered}
f(x)+f(1-x)=\frac{2}{2+4^{x}}+\frac{2}{2+4^{1-x}} \\
=\frac{2\left(2+4^{1-x}\right)+2\left(2+4^{x}\right)}{\left(2+4^{1-x}\right)\left(2+4^{x}\right)} \\
=\frac{8+8.4^{-x}+2.4^{x}}{8+8.4^{-x}+2.4^{x}} \\
=1
\end{gathered}
$$

b) Melihat dari sudut pandang lain

$$
\begin{aligned}
& f\left(\frac{1}{2014}\right)+f\left(\frac{2}{2014}\right)+\ldots+f\left(\frac{2013}{2014}\right) \\
& =\left(f\left(\frac{1}{2014}\right)+f\left(\frac{2013}{2014}\right)\right)+\left(f\left(\frac{2}{2014}\right)+\right. \\
& \left.f\left(\frac{2012}{2014}\right)\right)+\ldots+\left(f\left(\frac{1005}{2014}\right)+f\left(\frac{1009}{2014}\right)\right. \\
& )+ \\
& f\left(\frac{1007}{2014}\right)+\left(f\left(\frac{1006}{2014}\right)+f\left(\frac{1008}{2014}\right)\right) \\
& \text { Gunakan pola penyelesaian } \\
& \text { pada langkah a), sehingga } \\
& \text { diperoleh } \\
& =1+1+1+\ldots+f\left(\frac{1007}{2014}\right)+1 \\
& =\underbrace{1+1+1+1+\ldots+}+\underbrace{f\left(\frac{1007}{2014}\right)} \\
& 1006 \text { suku } \\
& \text { Suku tengah } \\
& =1006+f\left(\frac{1}{2}\right) \\
& =1006+\frac{2}{2+2^{\frac{1}{2}}} \\
& =1006+\frac{1}{2}
\end{aligned}
$$

$$
=\frac{2013}{2}
$$

d. Meneliti kembali pekerjaan yang telah dilakukan

Kita dapat meneliti kembali pekerjaan yang telah dilakukan dengan mengecek setiap langkah yang dilakukan apakah ada perhitungan yang terlewatkan atau tidak, ketelitian, dan apakah antara merencanakan strategi dan melaksanakan strategi telah sesuai.

4. Didefinisikan fungsi $f(\mathrm{n})=2^{\mathrm{n}-1}+2^{\mathrm{n}}$ $-2^{\mathrm{n}+1}$, untuk setiap bilangan asli $\mathrm{n}$. Nilai $\quad f(1)+f(2)+f(3)+f(4)+f(5)$ adalah ...

\section{(Olimpiade Sains Tingkat} Kabupaten/Kota 2015 Bagian A )

a. Memahami masalah

Diketahui:

$f(\mathrm{n})=2^{\mathrm{n}-1}+2^{\mathrm{n}}-2^{\mathrm{n}+1}$, untuk setiap bilangan asli $\mathrm{n}$.

Ditanya:

Nilai $\mathrm{f}(1)+f(2)+f(3)+f(4)+f(5)$

b. Menyusun strategi

Strategi yang akan digunakan adalah kombinasi strategi menyederhanakan masalah serupa dan strategi sudut pandang lain.

c. Melakukan strategi yang dipilih

a) Strategi menyederhanakan masalah serupa Dengan a bilangan asli

$$
\begin{aligned}
f(\mathrm{a}) & =2^{\mathrm{a}-2}+2^{\mathrm{a}}-2^{\mathrm{a}+1} \\
& =\frac{2^{a}}{2}+2^{a}-2^{a} 2 \\
& =\frac{2^{a}+2.2^{a}-4.2^{a}}{2} \\
& =-\frac{2^{a}}{2} \\
& =-2^{\mathrm{a}-1}
\end{aligned}
$$

Sehingga diperoleh

$f(\mathrm{a})=-2^{\mathrm{a}-1}$

$f(a)+f(a+1)=-3.2^{a-1}$ 
b) Melihat dari sudut pandang lain

$$
\begin{aligned}
& f(1)+f(2)+f(3)+f(4)+f(5) \\
& = \\
& {[f(1)+f(2)]+[f(3)+f(4)]+f(5)}
\end{aligned}
$$

Gunakan pola penyelesaian pada langkah a), sehingga diperoleh

$=\left(-3.2^{1-1}\right)+\left(-3.2^{3-1}\right)+\left(-2^{5-1}\right.$

)

$=-3-12-16$

$=-31$

d. Meneliti kembali pekerjaan yang telah dilakukan

Kita dapat meneliti kembali pekerjaan yang telah dilakukan dengan mengecek setiap langkah yang dilakukan apakah ada perhitungan yang terlewatkan atau tidak, ketelitian, dan apakah antara merencanakan strategi dan melaksanakan stratgei telah sesuai.

\section{KESIMPULAN DAN SARAN}

Dari penjelasan di atas, dapat disimpulkan bahwa dalam menyelesaikan permasalahan matematika non rutin bertipe penjumlahan fungsi dalam Olimpiade Sains Nasional Matematika SMP baik yang dimunculkan pada tingkat Kabupaten/Kota, Provinsi, maupun di tingkat Nasional , dapat diterapkan strategi kombinasi antara strategi menyederhanakan masalah serupa dan strategi melihat dari sudut pandang lain. Strategi menyederhanakan masalah serupa merupakan strategi yang dapat digunakan pada soal bertipe penjumlahan fungsi ketika kita berhadapan dengan permasalahan untuk menjumlahkan nilai-nilai fungsi dengan penjumlahan yang sangat banyak dan kompleks.

Strategi ini digunakan supaya dapat mempersingkat perhitungan dalam jumlah yang besar dan dilakukan dengan mencobakan permasalahan kompleks ke suatu bentuk serupa yang lebih sederhana, sehingga kita akan dapat menemukan suatu pola penyelesaian yang kemudian pola tersebut dapat diterapkan untuk permasalahan kompleks sebelumnya.

Sedangkan strategi melihat dari sudut pandang lain, apabila dalam menyelesaikan permasalahan matematika bertipe penjumlahan fungsi dengan menghitung secara langsung masing-masing nilai fungsi kemudian nilai-nilai fungsi tersebut kita jumlahkan sesuai yang ditanyakan memang memberikan solusi, tetapi belum tentu cara tersebut efisien. Terkadang, akan sangat menguntungkan apabila pemecah masalah mencoba melihat permasalahan dari sudut pandang yang lain atau pemecah masalah dapat merubah pandangannya terhadap permasalahan ke dalam bentuk lain, sehingga permasalahan tersebut akan lebih mudah diselesaikan dengan pola-pola penyelesaiaan yang terbentuk.

Apabila kita perhatikan secara cermat, susunan penjumlahan fungsi pada soal dapat dibuat menjadi susunan penjumlahan dalam bentuk lain yang sesuai dengan pola permasalahan pada langkah menyederha- nakan masalah serupa, namun hal ini tidak akan mengubah maksud soal. Selain itu, dengan melihat permasalahan dari sudut pandang yang lain akan lebih menguntungkan karena lebih mudah untuk menyelesaikan permasalahan tersebut dengan memanfaatkan pola penyelesaian yang terbentuk.

Dalam menyelesaikan permasalahan matematika non rutin bertipe penjumlahan fungsi, kita dapat memanfaatkan kombinasi strategi menyederhanakan masalah serupa dan strategi melihat dari sudut pandang lain sekaligus. Langkah pertama dengan 
mencobakan permasalahan yang ditanyakan pada soal ke dalam bentuk permasalahan yang serupa namun lebih sederhana, sehingga mendapat pola penyelesaian untuk masalah yang lebih sederhana. Langkah berikutnya dengan menerapkan strategi melihat bentuk susunan penjumlahan fungsi pada soal dengan sudut pandang yang lain sehingga susunannya menyerupai susunan bentuk penjumlahan pada pola penyelesaian strategi menyederhanakan masalah serupa.

Pada langkah terakhir kita dapat menerapkan pola penyelesaian yang didapat pada masalah sederhana ke permasalahan asli yang telah dirubah susunan penjumlahan fungsinya, dan dengan menerapkan langkah Polya permasalahan yang ditanyakan dapat diselesaikan dengan prosedur yang runtut..

Dengan memanfaatkan kombinasi strategi ini, perhitungan untuk menentukan hasil dari penjumlahan fungsi $f(x)$ untuk $\mathrm{x}$ yang dikehendaki dalam soal pada rentang nilai $x$ yang sangat besar dapat diselesaikan dengan lebih cepat, mudah dan efisien. Saran dalam kajian ini adalah penulis terbatas pada strategi pemecahan masalah menyederhanakan masalah serupa dan sudut pandang lain pada permasalahan non rutin penjumlahan fungsi SMP. Sedangkan strategi-strategi pemecahan masalah yang lain belum dibahas, sehingga dapat dilakukan pembahasan oleh penulis berikutnya.

\section{DAFTAR PUSTAKA}

Dhurori, A. \& Markaban. 2010. Pembelajaran Kemampuan Pemecahan Masalah Dalam Kajian Aljabar di SMP. Yogyakarta: PPPPTK Matematika.

Fajar, S. 2009. Sistem Pembinaan dan Karakteristik Soal Olimpiade Matematika. Yogyakarta: PPPPTK Matematika.

Hartono, Yusuf (Ed). 2014. Matematika Strategi Pemecahan Masalah. Yogyakarta. Graha Ilmu.

Sudarman, S. W. 2016. Analisis Problematika Pendidikan Matematika Berupa Soal Cerita Pada Siswa SD. Jurnal Aksioma. Vol. 5, No. 2, Hal 161-171. 